Original Research Paper

\title{
Production and Evaluation of Hydroxyapatite (HAp) Properties of Broiler's Composite Bone (BCB) Waste at Different Sintering Temperatures
}

\author{
${ }^{1}$ Muhammad Irfan Said, ${ }^{2}$ Effendi Abustam, ${ }^{3}$ Asdar Gani, ${ }^{4}$ Paulina Taba and ${ }^{5}$ Atirah \\ ${ }^{1}$ Lab. of Animal By-Products Processing Technology, \\ Faculty of Animal Science, Hasanuddin University, Makassar, Indonesia \\ ${ }^{2}$ Lab. of Meat and Egg Processing Technology, \\ Faculty of Animal Science, Hasanuddin University, Makassar, Indonesia \\ ${ }^{3}$ Department of Periodontology, Faculty of Dentistry, Hasanuddin University, Makassar, Indonesia \\ ${ }^{4}$ Department of Chemistry, \\ Faculty of Mathematics and Natural Sciences, Hasanuddin University, Makassar, Indonesia \\ ${ }^{5}$ Graduate of Animal Products Technology Study Program, \\ Faculty of Animal Science, Hasanuddin University, Makassar, Indonesia
}

Article history

Received: 06-10-2017

Revised: 28-03-2018

Accepted: 7-05-2018

Corresponding Author: Muhammad Irfan Said Lab. of Animal By-Products

Processing Technology, Faculty of Animal Science, Hasanuddin University, Makassar,

Indonesia

Tell/Fax: (+62-411) 587217

Email: irfan.said@unhas.ac.id

\begin{abstract}
Bone is one of the perishable livestock wastes, so serious attention is needed. The wastes are produced by Poultry Slaughterhouse (PSh) primarily in the process of separating meat from bone to produce boneless products. The main constituent of bone is the crystals $\mathrm{Ca}$ and $\mathrm{P}$, which are the major elements of Hydroxyapatite (HAp). The purpose of this study was to produce HAp from the Broiler's Composite Bone (BCB) waste as well as to evaluate the properties of $\mathrm{BCB}$ at different sintering temperatures. HAp was produced through 3 stages, i.e., calcination, precipitation and sintering. The calcination was carried out at $1000^{\circ} \mathrm{C}$ for 5 $\mathrm{h}$ and the resultant was evaluated by X-Ray Diffraction (XRD) and followed by precipitation with $\mathrm{HPO}_{4} 0.3 \mathrm{M}$. The next stage was sintering process, using 6 level temperatures of $550^{\circ} \mathrm{C}, 600^{\circ} \mathrm{C}, 650^{\circ} \mathrm{C}, 700^{\circ} \mathrm{C}, 750^{\circ} \mathrm{C}$, $800^{\circ}$ and followed by XRD analysis. The results showed that calcination at $1000^{\circ} \mathrm{C}$ for $5 \mathrm{~h}$ demonstrated the efficiency of $41.99 \%$. The intensity peak of calcination of the BCB was found at $2 \theta: 32.5250^{\circ}, 19.7200^{\circ}$ and $21.1200^{\circ}$ (before calcination) and $32.5187^{\circ}, 33.5626^{\circ}$ and $33.0000^{\circ}$ (after calcination). Sintering condition demonstrated significant effects on HAp yield. We also found that sintering process at $700^{\circ} \mathrm{C}(97.2 \%)$ was the most optimum temperature to produce HAp from BCB.
\end{abstract}

Keywords: Hydroxyapatite (HAp), Composite Bone, Broiler, Calcination, Sintering

\section{Introduction}

The waste products from poultry slaughterhouse (PSh) industry have remained a greater challenge (Enginuity worldwide LLC, 2017; Bodirsky et al., 2014; Khan and Ghouri, 2011) because of their susceptibility to deterioration (Centner, 2004). Bone constitutes is one of the most abundant solid wastes in PSh industry (Arshadi et al., 2015) and may transmit diseases. On the contrary, many beneficial applications of the bone were reported such as catalyst (Corro et al., 2016) and inexpensive organic fertilizer (Gousterova et al., 2008). Without further use, the bone waste might be a serious pollutant that contaminates air, water and soil, especially in PSh (Kazemi-Bonchenari et al., 2017). Bone contains a valuable component that needs to explore. It was reported to have a high content of calcium and phosphorus (Gopi et al., 2014). Its high mineral content may represent the adequacy of mineral supply contained in the feed (Onyango et al., 2003). As by-product, the bone is not only applicable for fabrication of feed, but also for environmentally friendly packaging material 
(Said et al., 2016; 2011). The broiler's composite bone refers to bone in the whole body except claw and head.

In Indonesia, the broiler's composite bone (BCB) is abundant and needs a further exploration. Based on MA (2015), broiler population reached 1,528.33 million. If assumed $70 \%$ of the population is slaughtered, the number of slaughtered broiler per month is 127.26 million $(70 \% \times 1,528.33$ million/12 months $)$. The bone waste accounts for $20.85 \%$ of total body weight. With average weight of $1.5 \mathrm{~kg}$ per head, the potential bone waste reaches 39.83 million $\mathrm{kg}$ per month $(20.85 \%$ $\times 191.04$ million $\mathrm{kg}=39.83$ million $\mathrm{kg}$ ).

In term of chemical components, the bone is rich in collagen and calcium (Ockerman and Hansen, 1999). Collagen extract is now widely used as an antiosteoporosis and anti-aging food supplement (English, 2011; English and Cass, 2001). Furthermore, duck beak bone was reported to be a promising source of of Hydroxyapatite HAp (Son et al., 2014). The collagen extract and HAp could be used as a composite material (Imanieh and Aghahosseini, 2013). Chest skin of broiler was also a good source of collagen, especially collagen type I (Bilgen et al., 1999). The extraction of collagen from bone produced HAp $\left[\mathrm{Ca}_{10}\left(\mathrm{PO}_{4}\right)_{6}(\mathrm{OH})_{2}\right]$ by $\pm 93 \%$ as by-product (Niakan et al., 2013; Gabriela et al., 2008). Previous studies reported that HAp could contribute to the bone regeneration (Kattimani et al., 2016) and serve as biomaterial in medicine science by means of HAp-collagen engineering (Shibata et al., 2005; Khiri et al., 2016; Heinz et al., 2010; Acharya et al., 2016). In dentistry, HAp was useful material for repairing and treating teeth and dental parts (Pepla et al., 2014; Görken et al., 2013).

The properties of HAp are highly depending on source and preparation conditions (such as heating temperature). The use of cattle's bone, shellfish and rock for fabrication of HAp has been studied (Khiri et al., 2016), whereas study pertaining broiler' bone composites for HAp production is rather scarce. This research was very important to increase the added value of $\mathrm{BCB}$ waste and reduce the pollution effect of PSh; thus, our study aimed to produce and evaluate the properties of HAp produced from broiler's composite bone at different sintering temperatures.

\section{Materials and Methods}

\section{Materials}

The BCB waste was obtained from PSh of Daya village, Makassar, Indonesia. The other materials included aquadest, $\left(\mathrm{NH}_{4}\right)_{2} \mathrm{HPO}_{4} 0.3 \mathrm{M}$, Whatman filter paper No.42 and aluminum foil. The instruments were X-Ray Diffraction (XRD) (Shimadzu 6000), furnace (Furnace 6000), oven (Memmert), analytical scale (Sartorius TE 214S), magnetic stirrer (C-MAG HS 7), thermometers, desiccators, stop watch (General), beaker glass (Pyrex), Erlenmeyer (Pyrex), measuring cylinders (Pyrex) and volume pipettes (Pyrex).

\section{Methods}

BCB waste $(180 \mathrm{~g})$ was cleaned from meat and fat, washed and then weighed. The HAp was produced by using three following stages, i.e., calcination, precipitation and sintering. The method was carried out according to Khiri et al. (2016).

\section{Stage 1. Calcination}

$\mathrm{BCB}$ was heated at $1000^{\circ} \mathrm{C}$ for $5 \mathrm{~h}$ using furnace, leading to removal of organic materials and conversion of $\mathrm{CaCO}_{3}$ into $\mathrm{CaO}$ through elimination of $\mathrm{CO}_{2}$ gasses (Equation 1). At this stage, the potential amount of waste was also determined. BCB $(60 \mathrm{~g})$ was transferred into 6 porcelain containers (10 g $\mathrm{BCB}$ per container). The Calcination Efficiency (CE) of the $\mathrm{BCB}$ was calculated as follow: $\mathrm{CE}=\mathrm{A} / \mathrm{B} \times 100 \%$, where $\mathrm{A}=$ weight $(\mathrm{g})$ of $\mathrm{BCB}$ after calcination; $\mathrm{B}=$ weight $(\mathrm{g})$ of $\mathrm{BCB}$ before calcination. XRD analysis was also performed to evaluate the resultant of calcination (using $\mathrm{CaO}$ as a standard) according to Joint Committee on Powder Diffraction Standard (JCPDS) 82-1691:

$\mathrm{CaCO}_{3} \rightarrow \mathrm{CaO}+\mathrm{CO}_{2}$

\section{Stage 2. Precipitation}

The calcined BCB was powdered using electrical grinder to obtain a particle size of $45 \mu \mathrm{m}$. The powder was used to prepare $1.0 \mathrm{M}$ of calcium hydroxide $(\mathrm{CaOH})_{2}$ solution by mixing with aquadest $(100 \mathrm{~mL})$ at $40^{\circ} \mathrm{C}$, as previously determined using a stoichiometric equation. The solution was stirred using a magnetic stirrer for $2 \mathrm{~h}$ to obtain a uniform mixture of $\mathrm{Ca}(\mathrm{OH})_{2}$. The reaction process occurs according to Equation 2:

$\mathrm{CaO}+\mathrm{H}_{2} \mathrm{O} \rightarrow \mathrm{Ca}(\mathrm{OH})_{2}$

To produce HAp powder, $\mathrm{Ca}(\mathrm{OH})_{2}$ suspension was added with $100 \mathrm{~mL}$ of phosphate acid $\left(\mathrm{HPO}_{4}\right)$ solution at a rate of 15-20 drops/min. Next, the solution was stirred with a magnetic stirrer and maintained at $\mathrm{pH} 8$ by adding ammonium hydroxide $\left(\mathrm{NH}_{4} \mathrm{OH}\right)$ solution to complete the reaction then stored for $24 \mathrm{~h}$ at room temperature. The ratio of $\mathrm{Ca}: \mathrm{P}$ was $1.67: 2$. The white precipitate formed was then filtered using Whatman no 42 paper and dried for $5 \mathrm{~h}$ at $110^{\circ} \mathrm{C}$. The results were weighed using analytic scales. The reaction process was presented in Equation 3:

$10 \mathrm{Ca}(\mathrm{OH})_{2}+6 \mathrm{H}_{3} \mathrm{PO}_{4} \rightarrow \mathrm{Ca}_{10}\left(\mathrm{PO}_{4}\right)_{6}(\mathrm{OH})_{2}+18 \mathrm{H}_{2} \mathrm{O}$ 


\section{Stage 3. Sintering}

Sintering refers to heating process below melting point to form a new crystal phase as desired. This process aims to assist chemical reactions of materials making up both ceramic and metal. The HAp powder was sintered at a temperature level of $550^{\circ} \mathrm{C}, 600^{\circ} \mathrm{C}$, $650^{\circ} \mathrm{C}, 700^{\circ} \mathrm{C}, 750^{\circ} \mathrm{C}, 800^{\circ} \mathrm{C}\left(50^{\circ} \mathrm{C}\right.$ intervals) using a furnace for $1 \mathrm{~h}$. After that, the HAp powder was cooled in a furnace at room temperature. The results were weighed to determine the efficiency. The Sintering Efficiency (SE) of $\mathrm{BCB}$ was calculated as follow: $\mathrm{CE}=$ $\mathrm{A} / \mathrm{B} \times 100 \%$, where $\mathrm{A}=$ weight $(\mathrm{g})$ of $\mathrm{BCB}$ after sintering, $\mathrm{B}=$ weight $(\mathrm{g})$ of $\mathrm{BCB}$ before sintering. Furthermore, to know the characteristics of $\mathrm{Ca}_{10}\left(\mathrm{PO}_{4}\right)_{6}(\mathrm{OH})_{2}$ produced, analysis using XRD (Shimadzu 6000) was carried out. The results of sintering were also analyzed using a diffractometer at the diffraction angle $(2 \theta)$ with scanning distance of $5^{\circ}$. The standard for characterization of HAp $\left(\mathrm{Ca}_{10}\left(\mathrm{PO}_{4}\right)_{6}(\mathrm{OH})_{2}\right)$ product followed the Joint Committee Powder Diffraction Standard (JCPDS) 18-0272.

\section{Parameters of Study}

The study parameters were (1) Calcination Efficiency (CE), (2) X-Ray diffraction of calcination, (3) Sintering Efficiency (SE) and (4) X-Ray diffraction of sintering.

\section{Experimental Design and Statistical Analysis}

The pattern of X-Ray diffraction (diffractogram) was descriptively analyzed, while CE and SE parameters. The data were evaluated using Analysis of Variance (ANOVA). Significant difference between means was compared using Duncan's Multiple Range Test (DMRT) at 5\% (Steel and Torrie, 1991).

\section{Results and Discussion}

\section{Calcination Efficiency (CE)}

The CE value is important to evaluate the effectiveness of the calcination process. High efficiency was expected in a production process. The $\mathrm{CE}$ of $\mathrm{BCB}$ at calcination condition of $1000^{\circ} \mathrm{C}$ for $5 \mathrm{~h}$ was presented in Table 1.

HAp, a type of bioceramic, has been widely used as an alternative material of artificial bone. It is selected for several biological reasons such as biocompatibility, bio-affinity, bioactivity, osteoconduction (Dubok, 2000), osteo-integration (Hench and Thompson, 2010) and osteo-induction (under certain conditions) (Weiner and Wagner, 1998). In composition, HAp was composed of calcium and phosphate ions, so there has been no reported adverse local or systemic toxicity. When HAp was applied to a new bone, it directly binds HAp through the apatite layer. This occurs because of the lack of calcium carbonate in bone implants (Dorozhkin, 2012; LeGeros, 2008).

The results showed that $\mathrm{CE}$ of $\mathrm{BCB}$ at heating temperature of $1000^{\circ} \mathrm{C}$ for $5 \mathrm{~h}$ to produce $\mathrm{CaO}$ was 41.99\% (Atirah, 2017). This CE was lower than that reported by Putri (2012) using different sources of bone, i.e., chicken egg shell of $(54.04 \pm 1.00)$, duck egg shell $(55.03 \pm 1.30)$ and quail egg shell $(53.19 \pm 3.00)$. The low $\mathrm{CE}$ can be caused by the insufficient temperature and processing time. The heating process eliminates all organic materials. Chicken bone shows a high crystallinity with single phase pattern. High crystallinity can increase the mechanical strength of the HAp. However, in excessive level of crystallinity, this may also complicate the absorption process in the body compared with other materials (Suzuki et al., 2005).

In recent years, the heating process was recommended to remove organic compounds (Lin et al., 1999). The crystalline phase composition of the sintered bone was similar to that of the natural bone of $93 \% \mathrm{HAp}$ $\left(\mathrm{Ca}_{10}\left(\mathrm{PO}_{4}\right)_{6}(\mathrm{OH})_{2}\right)$ of bone weight and about $7 \% \beta$ tricalcium phosphate $\left(\mathrm{Ca}_{3}(\mathrm{PO} 4)_{2}, \quad \beta\right.$-TCP) (Martin, 2000). The heat treatment yields an interconnected porous structure (up to $70 \%$ porous). Therefore, it allows for faster bone growth (Lin et al., 1999). The ratio of $\mathrm{Ca} / \mathrm{P}$ ratio also affects the mechanical properties of HAp. The greater the ratio of $\mathrm{Ca} / \mathrm{P}$ results in the higher strength, but the maximum ratio is 1.67 . The mechanical properties of HAp decreased at $\mathrm{Ca} / \mathrm{P}$ ratio of $>1.67$ or $<1.67$. In recent studies, many researchers have tried to extract HAp from natural materials such as coral, shell, eggshell, cuttlefish shells, natural gypsum and natural calcite (Herliansyah et al., 2012). The raw materials were $\mathrm{CaCO}_{3}$ or $\mathrm{CaSO}_{4}$. Some chemical reaction processes were performed to produce HAp. In our study, since BCB is from living beings, the production of HAp from $\mathrm{BCS}$ has certain advantages, including the reduction of polluted waste. Additionally, the BCB from Psh and meat processing industry is abundant and cheap. Thus, this suggests that the BCB may substitute the role of other natural ingredients.

\section{$X$-Ray Diffraction of Calcined $B C B$}

The diffraction profile of $\mathrm{BCB}$ was important to evaluate the potential content of HAp present in the sample. The standard used in this evaluation was Joint Committee on Powder Diffraction Standard (JCPDS) 82-1691 special for $\mathrm{CaO}$. The diffractogram of $\mathrm{BCB}$ before and after calcination at $1000^{\circ} \mathrm{C}$ for $5 \mathrm{~h}$ was obtained by using X-Ray Diffraction (XRD). As presented in Fig. 1, diffractogram shows a similarity pattern to JCPDS 82-1691. This indicates a process of converting $\mathrm{CaCO}_{3}$ into $\mathrm{CaO}$ by eliminating $\mathrm{CO}_{2}$ 
gasses Fig. 1. Demonstrates that BCB can be used as a candidate of bone replacement material according to its corresponding crystallinity properties. The BCB crystallization can be controlled by using different levels of time and temperature when the preparation process begins (Ooi et al., 2007).

Different intensity of X-Ray absorption in BCB before and after calcination is presented in Table 2.

Table 1: CE of of BCB at calcination condition of $1000^{\circ} \mathrm{C}$ for $5 \mathrm{~h}$

\begin{tabular}{llll}
\hline Repetition & Before calcination $(\mathrm{g})$ & After calcination $(\mathrm{g})$ & CE $(\%)$ \\
\hline 1 & 15.3255 & 6.2423 & 40.73 \\
2 & 12.7125 & 5.2624 & 41.40 \\
3 & 12.3155 & 5.1060 & 41.46 \\
4 & 10.5020 & 4.6418 & 44.20 \\
5 & 12.4025 & 5.1237 & 41.31 \\
6 & 7.4982 & 3.2124 & 42.84 \\
& Average & & $41.99 \pm 1.29$ \\
\hline
\end{tabular}

Table 2: Intensity of X-Ray absorption of BCB before and after calcination at $1000^{\circ} \mathrm{C}$ for $5 \mathrm{~h}$

\begin{tabular}{|c|c|c|c|c|c|c|c|}
\hline No & Peak No. & 2 Theta $(\theta)(\operatorname{deg})$ & $\mathrm{D}(\mathrm{A})$ & $\mathrm{I} / \mathrm{I} 1$ & FWHM (deg) & $\begin{array}{l}\text { Intensity } \\
\text { (Counts) }\end{array}$ & $\begin{array}{l}\text { Integrated } \\
\text { Int (Counts) }\end{array}$ \\
\hline \multicolumn{8}{|c|}{ a. Before calcinations Strongest 3 peaks } \\
\hline 1 & 14 & 32.5250 & 2.75069 & 100 & 1.73000 & 181 & 14456 \\
\hline 2 & 5 & 19.7200 & 4.49833 & 48 & 0.0000 & 87 & 0 \\
\hline 3 & 6 & 21.1200 & 4.20320 & 36 & 0.0000 & 66 & 0 \\
\hline \multicolumn{8}{|c|}{ b. After calcination Strongest 3 peaks } \\
\hline 1 & 19 & 32.5187 & 2.75121 & 100 & 0.51750 & 143 & 3637 \\
\hline 2 & 21 & 33.5626 & 2.66799 & 62 & 0.53870 & 88 & 2908 \\
\hline 3 & 20 & 33.0000 & 2.71218 & 44 & 0.00000 & 63 & 0 \\
\hline
\end{tabular}

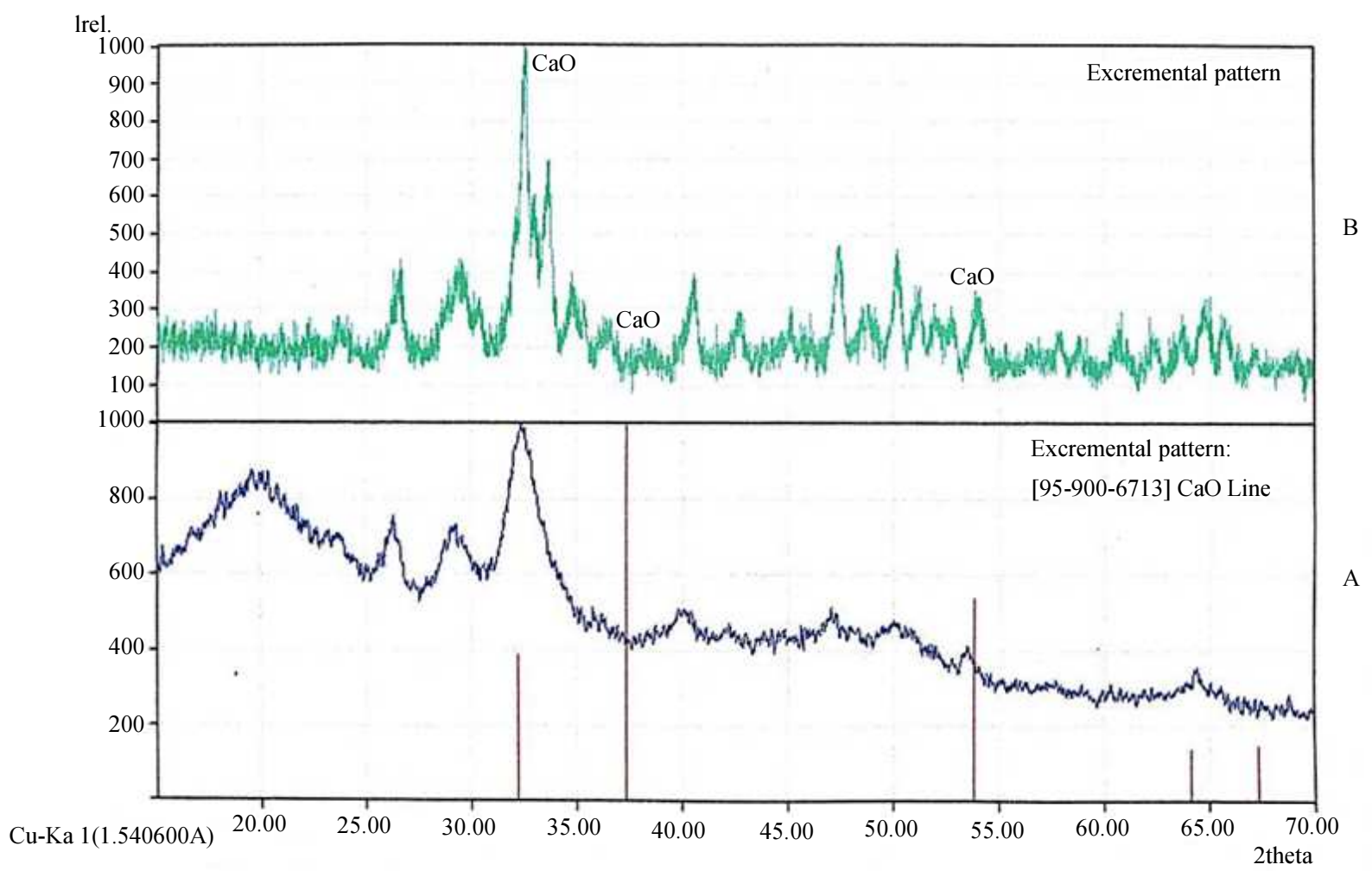

Fig. 1: Diffractogram of CaO crystal formation using X-Ray on BCB before (A) and after (B) calcination at $1000^{\circ} \mathrm{C}$ for $5 \mathrm{~h}$ 
Based on Table 2 and Fig. 1, we found the 3 highest peaks of $\mathrm{CaO}$ crystallization present before and after calcination. The crystallinity degree of $\mathrm{CaO}$ as the main HAp constituent can be observed from its diffraction patterns at the peaks. The maximum intensity peak of $\mathrm{BCB}$ was found at 20 : $32.5250^{\circ}$; $19,7200^{\circ}$ and $21,1200^{\circ}$ (before calcination) and $32,5187^{\circ} ; 33,5626^{\circ}$ and $33,0000^{\circ}$ (after calcination) (Atirah, 2017). The molarity of $\mathrm{Na}_{3} \mathrm{PO}_{4}$ affects content of $\mathrm{CaO}$. Higher level of $\mathrm{CaO}$ was responsible for higher purity degree of HAp. At molarity $>5 \mathrm{M}$, this may damage the crystal structure of the material, leading to reduction of $\mathrm{CaO}$ concentration.

\section{Sintering Efficiency (SE)}

The formation of HAp crystal involves sintering process after precipitation. The standard for characterizing HAp was the Joint Committee on Powder Diffraction Standard (JCPDS) 18-0272. The SE value was presented in Fig. 2.

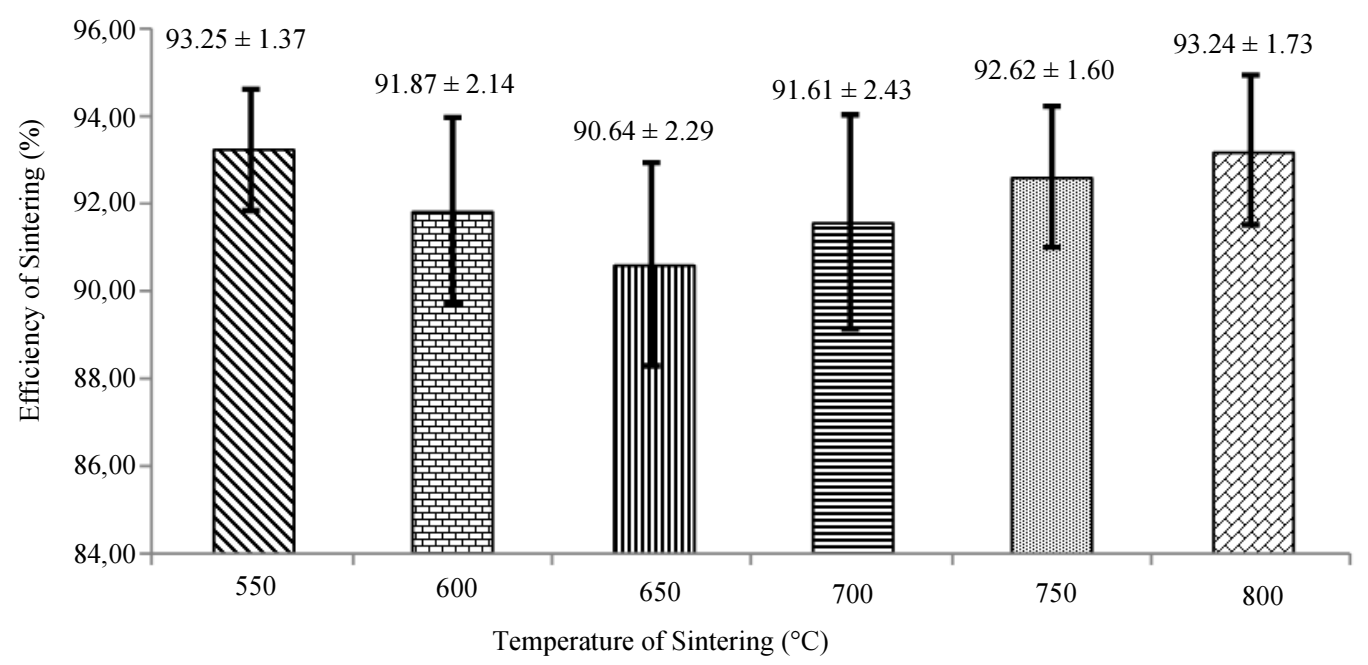

Fig. 2: $\mathrm{SE}$ of $\mathrm{BCB}$ after sintering process at various temperatures of $550-800^{\circ} \mathrm{C}$ for $1 \mathrm{~h}$ (temperature interval of $50^{\circ} \mathrm{C}$ )

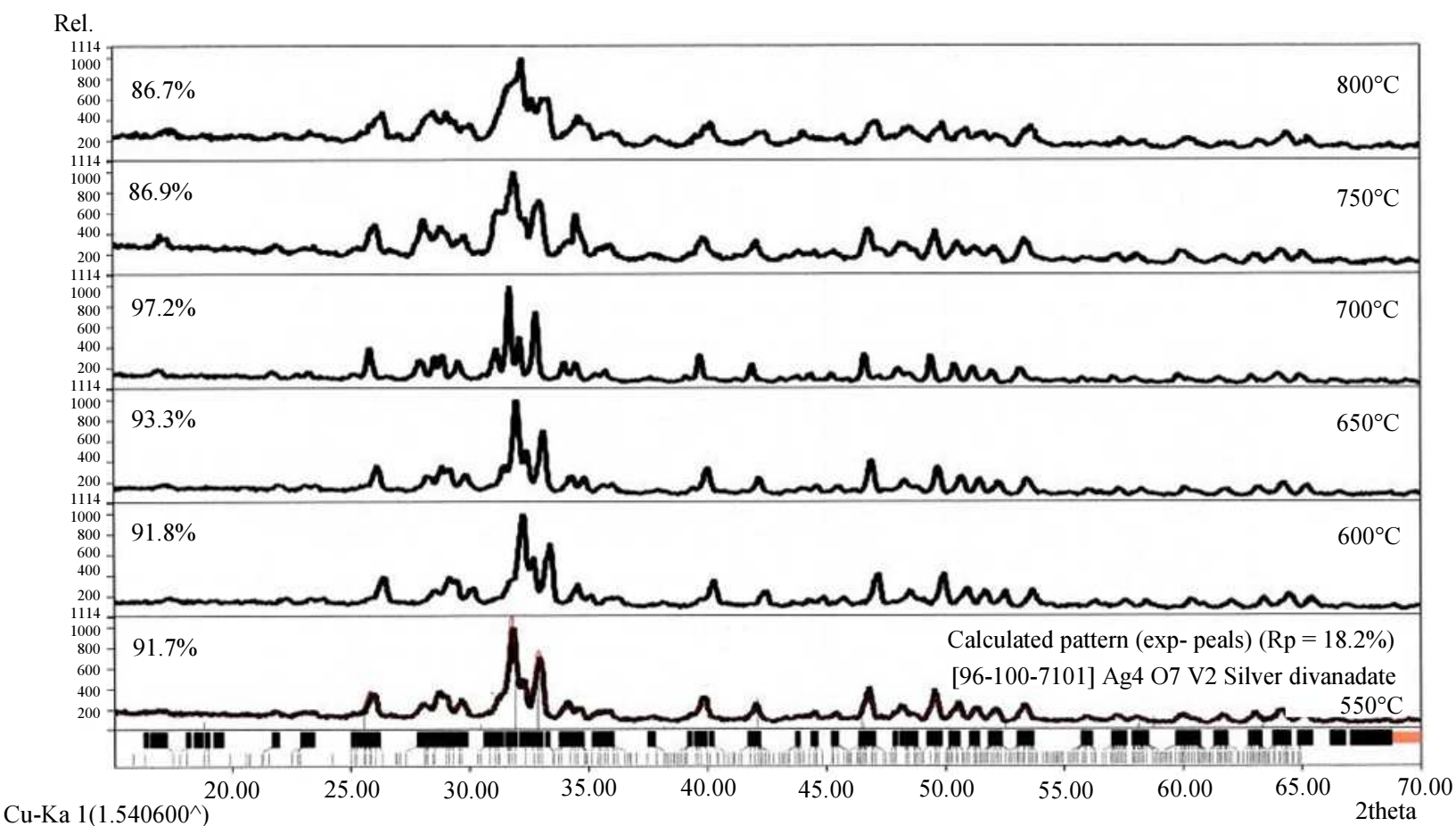

Fig. 3: Diffractogram of HAp formation using X-Ray of sintered BCB 
As depicted in Fig. 2, different sintering temperatures showed no significant effects on the amount of dried HAp precipitate $(\mathrm{p}>0.05)$. This suggests that sintering temperatures $\left(550-800^{\circ} \mathrm{C}\right)$ could be performed to produce HAp precipitates. The amount of dry sintering precipitates did not affect the levels of HAp in the precipitates. Therefore, to know the amount of crystal content of HAp, characterization using XRD was required (Fig. 3).

\section{$X$-Ray Diffraction of Sintered BCB}

Figure 3 exhibits the diffractogram of sintered BCB at temperature variations of $550-800^{\circ} \mathrm{C}$ for $1 \mathrm{~h}$. The results showed that sintering temperature of $700^{\circ} \mathrm{C}$ resulted in peak with the most optimum intensity, suggesting that this sintering condition could produce HAp crystallinity at optimum level. Powdered HAp has a great potential as the bone replacement. This is because it was easily absorbed by the bones and can be received by the body. There were two kinds of HAp powder, i.e., micro and nano sized HAp. Micro HAp has a small surface area and has a strong crystal bond, so that easily absorbed by the body. In addition, it can also increase biostability and strength. However, HAp with nanostructures has better density, strength and bioactive properties (Pepla et al., 2014).

\section{Conclusion}

The calcination process to produce $\mathrm{CaO}$ at $1000^{\circ} \mathrm{C}$ for $5 \mathrm{~h}$ resulted in $\mathrm{CE}$ of $41.99 \% \pm 1.29(\mathrm{n}=6)$. Diffractogram of maximum intensity of BCB before calcination was at $2 \theta: 32,5250^{\circ} ; 19,7200^{\circ}$ and $21,1200^{\circ}$, whereas after calcination was at $2 \theta$ : $32,5187^{\circ} ; 33,5626^{\circ}$ and $33,0000^{\circ}$. The sintering temperature $\left(550-800^{\circ} \mathrm{C}\right)$ showed no effect on a number of dry precipitates of HAp. The sintering temperature at $700^{\circ} \mathrm{C}(97.2 \%)$ was the most optimum sintering temperature to produce HAp from BCB.

\section{Acknowledgment}

The authors would like thank to the Ministry of Research, Technology and Higher Education, Republic of Indonesia, the Rector of Hasanuddin University (Unhas) and the Institute for Research and Community Service of Hasanuddin University for providing financial support under Research Grant Program of Riset Unggulan Unhas (Runas).

\section{Author Contribution}

Muhammad Irfan Said: Participating in all experiments, data analyzing and manuscript writing preparation.
Effendi Abustam: Participating in all experiments, collecting the field and performing statistical analysis.

Asdar Gani: Composing the experimental design and assiting data analysis.

Paulina Taba: Preparing the manuscript and analyzing data.

Atirah: Collecting the field data and contributing to the writing of the manuscript.

\section{Ethics}

This article is original and has not been published or presented elsewhere. All the authors have approved the manuscript and agree with submission to this journal. There is no conflict interest to be declared.

\section{References}

Acharya, G., P. Agrawal and G. Patri, 2016. Recent biomimetic advances in rebuilding lost enamel structure. J. Int. Oral Health, 8: 527-535.

DOI: $10.2047 /$ jioh-08-04-24

Arshadi, M., A.R. Faraji, M.J. Amiri, M. Mehravar and A. Gil, 2015. Removal of methyl orange on modified ostrich bone waste - A novel organicinorganic biocomposite. J. Colloid Interface Sci., 446: 11-23. DOI: 10.1016/j.jcis.2014.12.098

Atirah, 2017. Karakteristik hidroksiapatit tulang broiler pada suhu pembakaran berbeda. Skripsi. Fakultas Peternakan Universitas Hasanuddin, Makassar.

Bilgen, G., G. Oktay, Z. Tokgöz and S. Yalçin, 1999. Collagen content and electrophoretic analysis of type I collagen in breast skin of heterozygous naked neck and normally feathered commercial broilers. Turk J. Vet. Anim. Sci., 23: 483-487.

Bodirsky, B.L., A. Popp, H. Lotze-campen, J.P. Dietrich and S. Rolinski, 2014. Reactive nitrogen requirements to feed the world in 2050 and potential to mitigate nitrogen pollution. Nature Commun., 5: 3858-3858. DOI: $10.1038 /$ ncomms 4858

Centner, T.J., 2004. Developing institutions to encourage the use of animal wastes as production inputs. Agric. Human Values, 21: 367-375. DOI: $10.1007 / \mathrm{s} 10460-003-1223-5$

Corro, G., N. Sánchez, U. Pal and F. Bañuelos, 2016. Biodiesel production from waste frying oil using waste animal bone and solar heat. Waste Manage., 47: 105-113. DOI: 10.1016/j.wasman.2015.02.001

Dorozhkin, S.V., 2012. Calcium orthophosphates applications in nature, biology and medicine. Pan Stanford Publishing, Boca Raton, FL.

Dubok, V.A., 2000. Bioceramics-yesterday, today, tomorrow. Powder Metall. Met. Ceram., 39: 381-394. DOI: $10.1023 / \mathrm{A}: 1026617607548$ 
Enginuity worldwide L.L.C., 2017. Researchers submit patent application, process and products using a rotary compression unit. for approval (uspto 20170073598). Ecology, Environment Conservation.

English, J., 2011. Calcium dysregulation and osteoporosis. Nutrition Review.

English, J. and H.M.D. Cass, 2001. The Collagen connection. Nutrition Review.

Gabriela, V.R., D. Fournier, M. Teresa, R. Silva and J.L. Marty, 2008. Sensitive amperometric biosensor for dichlorovos quantification: Application to detection of residues on apple skin. Talanta, 74: 741-746. DOI: $10.1016 /$ j.talanta.2007.07.004

Gopi, M., M.R. Purushothaman and D. Chandrasekaran, 2014. Effect of dietary coenzyme Q10 supplementation on serum and bone minerals and leg weakness mortality in broilers. Vet. World, 7: 347-350. DOI: 10.14202/vetworld.2014.347-350

Görken, F.N., A.P. Erdem, G. Ikikarakayali and E. Sepet, 2013. The effects of nano-hydroxyapatite (nHAp) toothpastes on remineralization of enamel. Document Preview, 47: 81-88.

Gousterova, A., M.P. Nustorova, P. Christov, G.N. Nedkov and E. Vasileva-tonkova, 2008. Development of a biotechnological procedure for treatment of animal wastes to obtain inexpensive biofertilizer. World J. Microbiol. Biotechnol., 24: 2647-2652. DOI: 10.1007/s11274-008-9788-1

Heinz, B., A. Kasaj, M. Teich and S. Jepsen, 2010. Clinical effects of nanocrystalline hydroxyapatite paste in the treatment of intrabony periodontal defects: A randomized controlled clinical study. Clin. Oral Invest., 14: 525-531. DOI: $10.1007 / \mathrm{s} 00784-009-0325-\mathrm{x}$

Hench, L.L. and I. Thompson, 2010. Twenty-first century challenges for biomaterials. J. R. Soc. Interface, 7: S379-S391. DOI: 10.1098/rsif.2010.0151.focus

Herliansyah, M.K., C. Muzafar and A.E. Tontowi, 2012. Natural bioceramics bone graft: a comparative study of calcite hydroxyapatite, gypsum hydroxyapatite, bovine hydroxyapatite and cuttlefish shell hydroxyapatite. Proceedings of the Asia Pacific Industrial Engineering and Management Systems.

Imanieh, H. and H. Aghahosseini, 2013. Synthesis and character investigation of new collagen hydrolysate/polyvinyl alcohol/hydroxyapatite polymer-nano-porous membranes: I. experimental design optimization in thermal and structural properties. Syst. Synthetic Biol., 7: 175-184.

DOI: $10.1007 / \mathrm{s} 11693-013-9110-\mathrm{x}$

Kattimani, V.S., S. Kondaka and K.P. Lingamaneni, 2016. Hydroxyapatite-Past, present and future in bone regeneration. Bone Tissue Regenerat. Insights, DOI: 10.4137/BTRI.S36138
Kazemi-Bonchenari, M., A. Alizadeh, L. Javadi, M. Zohrevand and N.E. Odongo, 2017. Use of poultry pre-cooked slaughterhouse waste as ruminant feed to prevent environmental pollution. J. Cleaner Product. 145: 151-156.

DOI: $10.1016 /$ j.jclepro.2017.01.066

Khan, M.A. and A.M. Ghouri, 2011. Environmental pollution: Its effects on life and its remedies. Res.World J. Arts, Sci. Comm., 2: 276-285.

Khiri, M.Z.A., K.A. Matori, N. Zainuddin, C.A.C. Abdullah and Z.N. Alassan, 2016. The usability of ark clam shell (Anadara granosa) as calcium precursor to produce hydroxyapatite nanoparticle via wet chemical precipitate method in various sintering temperature. Springer Plus., 5: 1-15. DOI: $10.1186 / \mathrm{s} 40064-016-2824-\mathrm{y}$

LeGeros, R.Z., 2008. Calcium phosphate-based osteoinductive materials. Chem. Rev., 108: 4742-4753. DOI: $10.1021 / \mathrm{cr} 800427 \mathrm{~g}$

Lin, F.H., C.J. Liao, K.S. Chen and J.S. Sun, 1999. Preparation of a biphasic porous bioceramic by heating bovine cancellous bone with $\mathrm{Na}_{4} \mathrm{P}_{2} \mathrm{O}_{7} \cdot 10 \mathrm{H}_{2} \mathrm{O}$ addition. Biomaterials, 20: 475-484. DOI: 10.1016/S0142-9612(98)00193-8

Martin, R.B., 2000. Biomaterials. In: The Engineering Handbook, Dorf, R.C. (Ed.), CRC Press, Boca Raton.

MA, 2015. Livestock and Animal Health Statistics. Ministry of Agriculture, Republic of Indonesia, Jakarta.

Niakan, A., S. Ramesh, C.Y. Tan, M. Hamdi and W.D. Teng, 2013. Characteristics of Sintered Bovine Hydroxyapatite. Appl. Mechan. Mater., 372: 177-180. DOI: 10.4028/www.scientific.net/AMM.372.177

Ockerman, H.W. and C.L. Hansen, 1999. Animal ByProduct Processing and Utilization. 1st Edn., CRC Press, ISBN-10: 1566767776, pp: 544.

Onyango, E.M., P.Y. Hester, R. Stroshine and O. Adeola, 2003. Bone densitometry as an indicator of percentage tibia ash in broiler chicks fed varying dietary calcium and phosphorus levels. Poult. Sci., 82: 1787-1791. DOI: $10.1093 / \mathrm{ps} / 82.11 .1787$

Ooi, C.Y., M. Hamdi and S. Ramesh, 2007. Properties of hydroxyapatite produced by annealing of bovine bone. Ceram. Int., 33: 1171-1177.

DOI: $10.1016 /$ j.ceramint.2006.04.001

Pepla, E., L.K. Besherat, G. Palaia and G. Migliau, 2014. Nano-hydroxyapatite and its applications in preventive, restorative and regenerative dentistry: A review of literature. Annali Di Stomatol., 5: 108-114. DOI: $10.11138 / \mathrm{ads} / 2014.5 .3 .108$

Putri, A.A.M., 2012. Metode single drop pada pembuatan hidroksiapatit berbasis cangkang telur. Skripsi. Departemen Fisika. Fakultas MIPA, IPB, Bogor. 
Said, M.I., Y. Erwanto and E. Abustam, 2016. Properties of edible film produced using combination of collagen extracts of bligon goatskin with glycerol. Am. J. Animal Vet. Sci., 11: 151-159. DOI: 10.3844/ajavsp.2016.151.159

Said, M.I., S. Triatmojo, Y. Erwanto and A. Fudholi, 2011. Gelatin properties of goat skin produced by calcium hydroxide as curing material. Media Peternakan, 34: 184-189.

DOI: 10.5398/medpet.2011.34.3.184

Shibata, Y., H. Yamamoto and T. Miyazaki, 2005. Colloidal $\beta$-tricalcium phosphate prepared by discharge in a modified body fluid facilitates synthesis of collagen composites. J. Dental Res., 84: 827-831. DOI: $10.1177 / 154405910508400909$
Son, J.S., S.H. Jang, T.Y. Kwon, K.H. Kim and S.S. Kang, 2014. Preliminary evaluation of bone graft substitute produced by bone of duck beak. Mater. Lett., 121: 181-184. DOI: $10.1016 /$ j.matlet.2014.01.141

Steel, R.G.D. and J.H. Torrie, 1991. Principle and Procedure of Statistics. 2nd Edn., International Book Company, Tokyo.

Suzuki, Y., S. Matsuya, K.I. Udoh, M. Nakagawa and Y. Tsukiyama, 2005. Fabrication of hydroxyapatite block from gypsum block based on $\left(\mathrm{NH}_{4}\right)_{2} \mathrm{HPO}_{4}$ Treatment. Dental Mater. J., 24: 515-521. DOI: $10.4012 / \mathrm{dmj} .24 .515$

Weiner, S. and H.D Wagner, 1998. The material bone: structure-mechanical function relations. Ann. Rev. Mater. Sci., 28: 271-298.

DOI: 10.1146/annurev.matsci.28.1.271 